\title{
TV/Series
}

Hors séries 1 | 2016

Lost: (re)garder l'île

\section{The Autumn of the World}

\section{Pacôme Thiellement}

Translator. Brian Stacy

\section{OpenEdition \\ Journals}

Electronic version

URL: http://journals.openedition.org/tvseries/4981

DOI: $10.4000 /$ tvseries.4981

ISSN: 2266-0909

Publisher

GRIC - Groupe de recherche Identités et Cultures

\section{Electronic reference}

Pacôme Thiellement, «The Autumn of the World », TV/Series [Online], Hors séries 1 | 2016, Online since 01 December 2020, connection on 10 December 2020. URL : http://journals.openedition.org/ tvseries/4981; DOI : https://doi.org/10.4000/tvseries.4981

This text was automatically generated on 10 December 2020.

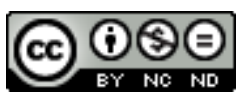

$T V /$ Series est mis à disposition selon les termes de la licence Creative Commons Attribution - Pas d'Utilisation Commerciale - Pas de Modification 4.0 International. 


\title{
The Autumn of the World
}

\author{
Pacôme Thiellement
}

Translation : Brian Stacy

1 We know not who we are. We live out lives shrouded in thickest fog, oblivious as to how our roles affect the fates of others and their roles on our own. In Lost, not only has almost every character already indirectly intervened in the lives of the other passengers, but their role has brought about profound changes affecting them to such an extent that they will all eventually wind up on the plane that spirits them away to the island. All are bound by ties so strong, so powerful, that they are as though caught in a terrible mesh, comparable to the tapestry that Jacob weaves when he's chosen as protector of the island. By choosing to operate on Sarah, Jack leaves Adam Rutherford, Shannon's father, to die, causing her to live miserably - it is her wretched existence that drives her to Sidney, where Boone goes to look for her. After winning the lottery, Hurley hires his former supervisor Randy at a box company, where he makes acquaintance of Locke, humiliated by Randy's constant insistence that he will never go on his much talked-about walkabout. Anthony Cooper, Locke's father, is responsible for the death of Sawyer's parents. Sawyer taught Cassidy the "trade" of con artistry, prompting her to meet Kate (who, in turn, advises to turn Sawyer in). And it was of course Daniel Faraday's mother, Eloise, who convinces Desmond not to marry Penelope, drawing him to the race around the world that lands him at the Swan Station pushing its fabled failsafe button for three years. In order to see Claire again, Jack's father, Christian, travels to Sydney where he meets Sawyer and unwittingly prevails upon him to kill the "fake Sawyer", putting him back on Oceanic Flight 815.

2 The thematic material dealt with in Lost has been likened with Frigyes Karinthy's hypothesis regarding Stanley Milgram's "six degrees of separation" or "small world". Karinthy penned the short story "Chain-Links" in 1929. In it, she explored the idea that advances in communications and transportation technology were expanding connectedness, causing the world to shrink. The short story spawned a number of contemporary writings, but Lost lends its premise with a special vibrancy - a mystical hue, that this shrinking "small world," has taken a turn for the fatefully providential. 
The ties that bind Lost's characters are never happenstance. Quite the contrary, they climax in an almost unbearable saturation of meaning.

No one knows who they are and what function they occupy in the personal stories of their loved ones, let alone in the history of mankind. This idea forms the overriding insight behind everything written by Léon Bloy, a late-19th century Catholic, polemicist, comic and doomsday novelist. We find this vision even in his short stories collectively entitled Disagreeable Tales:

What is the supreme, irresistible secret, the certain arcane, the Polichinelle sesame that opens the caverns of pathetic emotion and surely and divinely thrills the crowds? This famous secret is quite simply the uncertainty of people's identity. There is always someone who is not or who might not be the individual we suppose [...] Since Sophocles it hasn't changed. Don't you think, with me, that the imperishable power of an idea turned banal is the result of some very deep foreboding, questioned for three thousand years and since the beginning of time, by the trial and error that invented fables, like blind and desperate Oedipus seeking the hand of his Antigone. ${ }^{1}$ ?

4 To this theme, Lost adds a kind of special constant that all the "choices" made by the characters will systematically yield the same outcome, whether they are present-day "choices" or in the past decisions made by way of the time shifts featured in Lost's fifth season. And in these time shifts, whatever decisions the characters make, they fail to change anything, as their "choices" cancel one another out, bending back into an already-transpired past. Juliet helps Amy give birth to Ethan Rom, the man who will bring her to the island. Sayid tries to kill young Ben, but instead transforms him into an Other, and the wound inflicted on him, as well as Kate's choice not to let him die, ultimately leads Ben to Richard and the role of "new leader of the Others". The "Variable" concept expounded by Daniel Faraday in Lost's fifth season is a flagrant red herring. By setting off the hydrogen bomb at the site of the Swan Station, Lost's heroes trigger the "incident" that will maroon them together twenty years onward. On this point, Léon Bloy states:

What is called free will is similar to those plain flowers whose fluffy seeds are carried by the wind over sometimes great distances and in every direction, to be planted on unknown mountains or valleys. The revelation of these wonders will be a minute-long spectacle lasting all eternity. ${ }^{2}$

5 To view Lost series is to prepare for the show, to ready oneself for the revelation of wondrous happenings.

And that is the added value brings to the viewership experience. Not only are all the characters connected, but everything they go through somehow becomes a result of their actions. This explains the Buddhist adage appearing in the Season 3 episode "Not in Portland," during the scene when Kate and Sawyer set free Karl: "We are the cause of our own sufferings".

7 This imagery conveys both unfettered freedom and sheer determination, portraying the overarching story as a tightly-packed bundle. As if, between the first and fifth seasons, every detail etched into the characters' existences functions as a compact, dense narrative in which every detail counts and must lead them to their conclusion, the moment when Jacob is killed by Ben and Jack and company detonate the hydrogen bomb at the site of the future Swan station. Of these five seasons, nothing can be stripped away nor tacked on without the whole building collapsing. The slightest sentence uttered by a minor character exerts an effect on the whole, moving Lost's 
characters in a single direction. The image is therefore this tapestry, with one flaw - a rift in time (travel) - by which Jacob's brother, The Nameless Man, fulfils his goal: to assassinate Jacob and put an end to his magisterium.

This unbreakable interconnectedness among all characters is evocative of universal interdependence. Dating from ancient times, the concept has taken on new meaning now that the known world's been mapped out and laid over with grid, and that online devices and social networks are effectively capable of bringing together any one person to anyone else. As Raymond Abellio (whose Absolute Structure attempts to produce a yoga capable of combining state-of-the-art science with ancient traditional esoterics) has repeatedly pointed out, this idea is scientifically supported from a material point of view - the mere act of raising one' $s$ arm is sufficient to throw off the gravity of the universe (Abellio added: "the slightest feeling, the slightest emotion and the slightest thought is also part of the indefinite fabric of the universe" 3 ; Abellio developed a Brahmanic school of thought ${ }^{4}$ overlapping with the kind of thinking prominent in Lost). This "butterfly effect," named after the 1972 lecture by meteorologist Edward Lorenz ("Can a butterfly flapping its wings in Brazil cause a tornado in Texas?"), retroactively implies that we cannot change anything in world history. We cannot remove anything from world history that does not affect it to the point of making it incompatible with our own past, just as we cannot add anything to it that would in any way alter it permanently. Lost remains firm on this point and refrains from introducing "time paradoxes". Whatever happened, happened, or to once again quote Raymond Abellio: "Abandon the conditional. What is, and what must be, will be." This is what Lost reasserts and seeks to bear out over and over again. ${ }^{5}$

9 Not only does this apply to the lead characters, but more minor characters as well. All of them do their part to stitch together the huge and terrible mesh. By reviewing episodes from Lost, what we see is that almost every character featured is a potential oracle; almost all lines are portentous: Michael's wife's lawyer heralds Bea's later remark that, for a father so bent on obtaining custody, he doesn't seem to know his son all that well. A doctor says to Locke, "I don't want to hear you tell me what you can't do." Everyone from judges to pharmacists to fortune tellers to random passers-by seem to intuit how the characters feel. In addition, any official from a research firm who gives you an audience could be Richard, the island's envoy. Any nurse pushing your wheelchair could be Matthew Abaddon, Charles Widmore's "angel" ("I'm much more than just a nurse"). Any stranger who helps you pick up your candy bar when you're in a sour mood at the hospital could be Jacob. In the "Whatever happened" episode, even the woman who looks like Claire and with whom Aaron was starting to leave in the supermarket when Kate momentarily loses sight of him seems to be somehow tasked with driving her back to the island. As in the writings of Léon Bloy, what matters in Lost is uncertainty about people's identities - and the possibility that anyone could be "much more than just a nurse. This assumption, fundamental to Léon Bloy's work, stems in part from Naundorffism, the widely-held 19th century belief that Louis XVI's son had survived by escaping from the Temple prison and living in exile under the pseudonym Karl-Wilhelm Naundorff. This craze shares a fundamental feature common to many beliefs and traditions: the Messiah in Judaism, the Hidden Imam and the Khezr in Islam - even the avatars of Hinduism who can take human forms (as in The Baghavad Gita in which Krishna masks himself as Arjuna's coachman). A writer who has read a lot 
of Bloy and who has often used him for his tales, Jorge Luis Borges, wrote the following particularly relevant comment about him:

No one knows who he is, said Léon Bloy. Nobody better than he to illustrate this intimate ignorance. He thought he was a rigorous Catholic, and he was a follower of the cabbalists, a secret brother of Swedenborg and Blake: heretics ${ }^{6}$.

One might even add that everyone's possession of a secret identity is a kind of Gnostic idea - for the main theme of the Gnostics, the anamnesis, as recounted in the "song of the pearl" found in the Acts of Thomas, for example, repeatedly makes mention of the inherent nobility of the man who is born a tramp or beggar, but who is nevertheless the son of a prince. It is all but a matter of examining one's life, of studying individual lives and their deeper meaning in the course of History.

11 No one knows to whom they're speaking. It's something to be simply experienced or felt, but this feeling can veer in two directions: that, paranoid, of the Great Conspiracy (where the first half of the story seemed to be leading, a compendium of phony markings, Widmore Labs ads, and the like) or the symbolic direction in which everything that happens is more than meets the eyes. What gave the first half of Lost a "Rivettian" feel was the kind of blanket uncertainty, the potentially all-encompassing "conspiracy" inhabiting the series until its meaning emerged. We're shown a photo of Eloise Hawking in the office of the monk hosting Desmond, Brother Campbell, or a model of Black Rock in Widmore's office, or the same character, Kelvin Inman, teaching Sayid how to torture in Iraq and keeping Desmond prisoner at the Swan Station. All these scenes combined convey the impression that the characters were strung like puppets by a powerful organization - and, indeed, in some ways they were, but there was no political conspiracy wrought, nor any purely man-made decisions made. The Nameless Man's accusation against Jacob holds water: Jacob came at a moment of weakness and guided each of the candidates - so their choices were not really theirs. This comes out at the end of the third season when Jack says to Kate: "we weren't supposed to leave", and again in the fourth season when the Others begin to invoke the "will of the island" as that of an intelligent being or sentient supernatural entity: This is evidenced when Tom says to Michael, for example: "You can't kill yourself. The island won't let you." In Lost, everyone is only doing what the island, through Jacob, its "protector", expects of them. The image conveyed is one of the world as a sacred tapestry - or liturgical text. As Léon Bloy writes again:

History is like an immense liturgical text in which iotas and dots are worth as much as entire verses or chapters, but the importance of each is indeterminable and deeply hidden ${ }^{7}$.

As time does not exist for God, the inexplicable victory at the Battle of the Marne could have been decided by the humble prayer of a little girl born two centuries later.

Lost is a liturgical series wherein each detail has as much value as an entire episode; for each detail can be the blow of a stick that will generating satori9: "I think I liked it better when you hit people with your stick" Bernard tells Mr. Eko when he becomes a quotable priest. The best way to watch Lost is to examine one's own life through the prism of its episodes.

One must find that image which coincides with one's own questions, the outline of one's own problems. In our lives too, the tiniest details matter. Tucked away in the most minute detail of our lives, there is a prophetic window there to let us know what 
"we're supposed to do". The series is to the viewer as the island to the character: it won't let us away until we've done what we're supposed to.

One of the most salient episodes on this topic is "Cabin Fever" in the fourth season: it presents, across a handful of sequences separated in time by more than fifty years, select moments when John Locke's life was affected by the will of the island. We see his birth as a miracle baby, mightier than all the illness and suffering surrounding him and we see Richard Alpert in attendance at his birth, gazing on the baby in the manner of a Wise Man or a fairy godmother. We also see Locke being bullied as a youngster by his classmates, and refusing an offer to enrol in a science camp run by Mittelos Bioscience, the Others' "front company" outside the island. In this scene, Locke's teacher sounds like an oracle when he calls on Locke to stop fighting his true nature, telling him, "You're a scientist. You will never be a superhero." We see Locke in his wheelchair, approached by Matthew Abaddon, Widmore's angel, advising him to go on a walkabout and assuring him that they'll meet again. But the most critical sequence is the one in which Richard comes to meet Locke for a test. First, he spots a dreamlike illustration on the wall of young Locke pointing out a swath of black smoke attacking humans. Then he holds up several objects before him and asks him which one already belongs to him: a baseball glove; a vial containing some sand; a compass; a comic book; a Book of Laws; and a knife. John Locke chooses the knife and Richard reckons that Locke isn't ready yet, before stealing off into the rain like a thief. I have long believed that the object Locke should have chosen was The Book of Laws - from the way Richard looks at it when he walks up to the book, and from the musical theme that plays. But in reality, it's more likely to be the compass - since Richard already gave it to Locke in the past. Therefore, it already belongs to him. The Book of Laws, on the other hand, does not belong to him any more than it does to someone else. And above all, it won't be featured throughout the remainder of the story.

"We will show them Our signs in the horizons and in their souls," says God in a famous verse from Sura 41 of the Quran ${ }^{10}$. From this verse, Haydar Amoli deduced that two other sacred books ought to be added to the Bible and the Qur'an: the Book of Horizons and the Book of Souls ${ }^{11}$. It is not the Book of Laws that Lost will examine but the Books of Horizons and Souls. The Book of Laws sets out the ideas of a scriptural religion - a pre-existing text to be used as a point of reference. But Lost offers another point of reference, a compass. This compass has a peculiarity: it was never been destroyed and was never built. It is not beholden to worldly contingency and passes round from John's hand to Richard's hand. Richard gives it to Locke in 2007 (featured in the episodes "Because you left" and "Follow the Leader"), and Locke gives it back to Richard in 1954 in "Jughead". The compass has neither past nor future, it is embedded within the story of Lost like a clasp holding together the weave of a tapestry. This compass is the truest symbol of Lost. The series serves as a wayfinder compass in the vast tapestry that is the History of this world.

17 So the question is: towards which event is this tapestry stretched? What is expected from this succession of actions and reactions - if not the advent of a new protector? Lost viewers are characterized by their understanding of universal interdependence. The time of Lost is an era in which the cultural-religious discourse of yesteryear has ceased to be but no new language has yet come into being. It is a time of great tribulation, a time of restless peoples. It is also a time when, in the words of Abellio: "It is not the man who is in the Temple, but the Temple which is in the $\operatorname{man}^{12}$." 

First of all, in the sense that the show's universe is limited to the enclosed space of a prison. The prison of $\mathrm{Oz}$ is the island in Lost: everyone wants to get out, and everyone will die there - or almost everyone (the handful of survivors of both series seem to be there only out of a heightened preoccupation for realism, or not to finish out their lives in gruesome fashion, but they fail to change anything about the "triumph of death" that brings their stories to an end). There is no more a way out of the prison of $\mathrm{Oz}$ than there is out of this life. The only "exit" being death, the question is the characters' deliverance, the deliverance from their passions, their way out of the Buddhist "labyrinth" of this life. That's why the series most clearly articulating the issues and problems of Lost is Oz. This can be understood in several ways: finding one's talent - as with Omar White; making peace with oneself as with Kareem Said; being certain of the unconditional love that the ambiguous Chris has for him, as with the lawyer Tobias Beecher, even if this love has postponed his remission; taking care of his brother as with Ryan; and winning the love, however impossible, of Dr. Gloria Nathan. But above all, as Oz unfolds, the main issue seems to be that of the guard, custodian of others' sufferings and steward of their hopeful redemption. It is Tim MacManus' redemptive function that is continually emphasized, guided by two clergy, Father Ray Mukada and Sister Peter Marie, not to mention the charismatic and hugely endearing prisoner, Imam Kareem Said. In Lost, Jack, Hurley, Locke, Sawyer, Sayid, and the Kwons are candidates. Their election takes its meaning from their unfitness to live in our world but also from their nobility. The beauty of their souls. In the Christian vernacular, they would appear to have saintly potential. This is also the case with Tim MacManus in Oz, as with Augustus Hill, Kareem Saïd, Bob Rebadow, Ryan O'Reilly, Tobias Beecher, Miguel Alvarez - even though they're all extremely damaged. Some of the characters in Lost are themselves quite damaged... What characterizes the candidates is their exceptional self-sacrifice - their inability to act selfishly or in a base or self-serving way.

In the intervening period between two eras, namely the end times, sanctity is no longer the preserve of a formal religion, of an institutional religion, but is determined by more diffuse spiritual impulses, "osmotic", as Abellio would say. This intervening period, the "end times," is explored in the later seasons of both $\mathrm{Oz}$ and Lost, Oz's final season being set in the time between the death of the coryphaeus, Augustus Hill, and that of the prison warden, Leo Glynn, and of Vernon Schillinger, his worst inmate - and Lost's, between Jacob's and the Nameless Man. As the title of episode 6 of the sixth season says, it is the Autumn of the World, the "sundown". Season six is the season of the apocalypse, because Jacob is no more and all the characters are, at last, free to make their own choices. Symbolically, the spirituality specific to the Lost era has faded away and a new kind has not yet appeared. As a result, the events no longer have the symbolic power that permeates the depths of the previous five seasons, but they appear in a chaotic, almost random way: successive explosions and destruction of the Temple, Black Rock, the submarine... Just as the History of Humanity, "our" History, is stretched taut towards its end, which will be a full restart, the entire show is outstretched toward its own conclusion, "The End", which announces that the now-conscious viewer's time is up. The main narrative of the sixth season is a string of disasters. Many characters appear and disappear, without viewers hoping to find out much about them, starting with Illana, introduced in the fifth season and who remains a virtual stranger to us, along with Dogen, Lennon, Zoé and others... The characters never manage to settle 
down anywhere on the island, but they never stop moving: unlike the previous seasons, there is construction of a new place (the Temple is destroyed after seven episodes). They instead incessantly wander from place to place until the finally discovering the light source.

The time of the sixth season is a time of darkness - of sickness; this sickness is the will to be over with, it is disgust, bitterness - it is the sinking downward and the end of spiritual impulses, gradually destroying all ethics, all sense of justice, all sense of dignity: in Lost, reference is made to "recruitment" through sickness. The "recruits" of the Nameless Man all share an intellectual and moral opacity that is slowly growing within them. It is born out of despair, out of the inability to find any meaning in this life - out of a return to an original state of wandering unable to produce new ties or bonds. We see it for a time in Claire, Sayid, Ben, Sawyer. They have come loose, become disconnected. There is, however, an opposite state which is that of a candidate. In the intervening period, men are divided between candidates and recruits. In both cases, it is a matter of the way one looks back on life. What Lost does is to prepare its viewer to contemplate life, to look back over the lives they've led. Joseph de Maistre writes:

We must be ready for an immense event in the divine order towards which we are advancing with an increasing speed that ought to astound all observers. Dire oracles are already announcing that the time has come ${ }^{13}$.

21 The Lost TV series is like a far-reaching preparation for this great event. An event where what will matter won't be so much our physical preparation as our spiritual readiness. It is not our strength that is being put to the test, it is our gaze. This is why the new protector, the one in whom viewers will see themselves epiphanized, will also be the weakest character in terms of action, Hurley, but the one whose intentions are the purest, the one whose gaze is the least obstructed by his own weaknesses or failings. The viewer is prepared to achieve a new kind of gaze, and those quality is the main tenet of the whole series - and of which many episodes kick off with the eye of a character waking up. The subject of Lost is being born again - or more precisely for one's rebirth. If we're to believe in the Lost experience, we must envision its viewers as being summoned to a spiritual protectorship, and, like that of Jack, this protectorship is temporary - it is to last through the intervening period, the time of tribulation: the Autumn of the World.

We are in the autumn of the world. The vegetation of the souls is interrupted and winter draws nigh with all its horrors ${ }^{14}$.

\section{NOTES}

1. Léon Bloy, "Propos Digestifs", Histoires désobligeantes (1914), CEuvres vol. VI, Paris, Mercure de France, 1967, p. 311.

2. Léon Bloy, "La communion des saints !...", Méditations d’un solitaire en 1916 (1916), CEuvres vol. IX, Paris, Mercure de France, 1969, p. 239.

3. Raymond Abellio, "Autoportrait", Approches de la nouvelle Gnose, Paris, Gallimard, 1981, p. 13

4. That is to say, favoring contemplation over action. 
5. Sentence attributed to his mentor Pierre de Combas, Raymond Abellio, De la politique à la gnose, interviews with Marie-Thérèse de Brosses, Paris, Belfond, 1987, p. 47.

6. Jorge Luis Borges, "Le miroir des énigmes", Enquêtes (1957), Paris, Gallimard, 1967, p. 165.

7. Léon Bloy, L’Ame de Napoléon (1912), Euvres vol. V, Paris, Mercure de France, 1966, p. 273.

8. Léon Bloy, "La communion des saints !... ", Méditations d'un solitaire en 1916 (1916), CEuvres vol.

IX, Paris, Mercure de France, 1969, p. 240.

9. Satori, in Zen Buddhism, is an enlightenment that enables lasting understanding or realization. It can be achieved in many ways, through an obscure, enigmatic or paradoxical utterance (the koan), sustained attention, or even being hit by the Zen master's stick!

10. Le Coran, XLI, "Les Versets clairement exposés", v. 52.

11. Henry Corbin, "La Science de la Balance", Temple et Contemplation (1958), Paris, Entrelacs, 2006, p. 118.

12. Filmed interviews with Dominique de Roux and Jean-José Marchand, 1977 (INA archives).

13. Joseph de Maistre, " $11^{\mathrm{e}}$ Entretien", Les Soirées de Saint-Petersbourg, cited by René Guénon, Le Roi du Monde (1927), Paris, Gallimard, 1958, p. 97.

14. Léon Bloy, "L'avènement inimaginable", Dans les ténèbres (1918), CEuvres vol. IX, Paris, Mercure de France, 1969, p. 317.

\section{ABSTRACTS}

Lost works as an orienting compass in the vast tapestry that World History is, and the spectator of Lost, as the new protector of the island, is a spectator whose gaze is progressively educated through the sense of universal interdependence.

Lost fonctionnerait comme une boussole d'orientation dans la vaste tapisserie qu'est l'Histoire de ce monde, et le spectateur de Lost, nouveau gardien de l'île, serait un spectateur dont le regard s'éduque peu à peu par le sens de l'interdépendance universelle.

\section{INDEX}

Mots-clés: Lost, lien, identité, interconnexion, gnose, anamnèse, épiphanie, gardien, texte sacré, orientation

Keywords: Lost, link, identity, interconnectedness, gnosis, anamnesis, epiphany, protector, sacred text, orientation

\section{AUTHORS}

\section{PACÔME THIELLEMENT}

Pacôme Thiellement is a writer born in 1975 in Paris. Among his books: Poppermost (MF, 2002); La main gauche de David Lynch (PUF, 2010); Les mêmes yeux que Lost (Leo Scheer, 2011) ; Pop Yoga (Sonatine, 2013); Cinema Hermetica (Super-8, 2016). 
Pacôme Thiellement est un écrivain né en 1975 à Paris. Parmi ses différents livres : Poppermost (MF, 2002) ; La main gauche de David Lynch (PUF, 2010); Les mêmes yeux que Lost (Leo Scheer, 2011) ; Pop Yoga (Sonatine, 2013) ; Cinema Hermetica (Super-8, 2016). 